\title{
5 Determinants of Crop Growth and Yield in a Changing Climate
}

\author{
P.K. Aggarwal \\ Indian Agricultural Research Institute, New Delhi 110 012, India; \\ email: pkaggarwal.iari@gmail.com
}

\section{Introduction}

The world population has crossed 6.7 billion; almost $20 \%$ of these people live in South Asia. The population of the world, especially of South Asia, continues to increase, even now, at a significant rate. This rapid and continuing increase in population implies a greater demand for food. Rice production in Asia alone must increase to more than 800 million $\mathrm{t}$ over the next 20 years (Hossain, 1995). Cereal requirements of India alone by 2020 will be between 257 and 374 million t (Rosegrant et al., 1995; Kumar, 1998; Bhalla et al., 1999). Demand for pulses, fruits, vegetables, milk, meat, eggs and marine products is also expected to increase very sharply. This additional food will have to be produced from the same, or even a shrinking, land resource base because there is no additional land available for cultivation.

Although the world as a whole has sufficient food for everyone and perhaps will continue to have in future as well, the widespread poverty in many countries prevents access to food. Today, even after several 'revolutions' in agriculture, almost 800 million people, who almost entirely live in the developing world, go hungry (FAO, 2006). About two-thirds of the undernourished in the world live in Asia. In the 21st century, one of the great challenges will be to ensure that food production is coupled with both poverty reduction and environmental protection.
The Intergovernmental Panel on Climate Change (IPCC), in its recently released report (IPCC, 2007a), has reconfirmed that the earth's temperature has increased by $0.74^{\circ} \mathrm{C}$ between 1906 and 2005. There is also a global trend for increased frequency of droughts, as well as heavy precipitation events over most land areas. Cold days, cold nights and frost have become less frequent, while hot days, hot nights and heatwaves have become more frequent. The IPCC has projected that the temperature increase by the end of this century is likely to be in the range 1.5 to $4.0^{\circ} \mathrm{C}$. It is also likely that in future tropical cyclones will become more intense, with larger peak wind speeds and heavy precipitation. Himalayan glaciers and snow cover are projected to contract. Increases in the amount of precipitation are very likely in high latitudes, while decreases are likely in most subtropical land regions.

Such global climatic changes will affect agriculture through their direct and indirect effects on crops, soils, livestock and pests. Global studies have indicated a loss of $5-40 \%$ cereal production by $2100 \mathrm{AD}$ due to global warming, threatening the food security of several countries (Rosenzweig and Parry, 1994; Easterling et al., 2007). Thus, there is a tremendous challenge facing agricultural scientists to develop technologies for increasing food production in the coming decades. There is an urgent need to secure the past yield gains and further increase the potential yield of major food crops. 
High potential crop yields can be achieved/ realized in future either by reducing yield gaps or by raising yield potential. For example, the potential yields of rice and wheat are calculated to be more than $6 \mathrm{t} /$ ha in India whereas their average yields range between 2 and 3 t/ha (Aggarwal et al., 2000). Such large yield gaps can be tapped in future for ensuring food security in the scenario of adverse climatic impacts. Institutional support in the form of improved extension services, markets and infrastructure needs to be provided in such regions to increase stability and bridge yield gaps. Raising yield potential is, however, important for regions where yields are already high and are stagnating, such as in Punjab, India.

Determination of the productivity potential of a crop requires a thorough understanding of crop growth and development. These, in turn, are dependent upon several climatic, edaphic, hydrological, physiological and management factors. The major factors affecting crop growth and development are radiation, temperature (yield determining), water, nutrition (yield limiting), and pests and diseases (yield reducing) (Van Ittersum and Rabbinge, 1997). In addition, productivity is also determined by many other factors, such as cultivar, its physiology and crop management, which interact with weather and soils to influence yield level. In irrigated and well-managed crops, productivity is primarily determined by radiation and temperature, whereas in rainfed areas, rainfall and soil moisture storage are of prime importance. In this chapter, our objective is to discuss the key determinants of crop growth and yield in a global scenario of changing climate.

\section{Key Determinants of Crop Growth and Yield}

\section{Crop-climate interactions}

Atmospheric carbon dioxide $\left(\mathrm{CO}_{2}\right)$ concentration has reached $381 \mathrm{ppm}$ today, from a low level of $280 \mathrm{ppm}$ in $1750 \mathrm{AD}$. It is now rising at a rate of 1.8-2.0 ppm per year (IPCC, 2007a). Increase in atmospheric $\mathrm{CO}_{2}$ has a fertilization effect on crops with a $\mathrm{C}_{3}$ photosynthetic pathway and thus promotes their growth and productivity. The $\mathrm{C}_{4}$ crops are not known to significantly benefit from further $\mathrm{CO}_{2}$ increase. Increased $\mathrm{CO}_{2}$ also results in increased water use efficiency of all crops. Under field conditions, however, response to enhanced $\mathrm{CO}_{2}$ is moderated by other environmental constraints. Long et al. (2006) have recently shown that the yield enhancement with high $\mathrm{CO}_{2}$ is only to the extent of $10-15 \%$ in field-grown cereal crops, as against $20-30 \%$ response documented earlier (Kimball et al., 2002). Using a crop model, Aggarwal (2003) showed that the benefit of enhanced $\mathrm{CO}_{2}$ was moderated by nutrient and water constraints in wheat.

Several approaches have been tried earlier by scientists to raise yield potential through manipulation of source and/or sink. The International Rice Research Institute (IRRI) has been trying to develop a new plant type of rice, with a yield potential $20-25 \%$ higher than that of existing semi-dwarf rice varieties, through ideotype breeding approaches (Khush, 1995) for tropical environments. The proposed plant type has a low tillering capacity (three to four tillers when directseeded), few unproductive tillers, 200-250 grains per panicle, a plant height of $90-100 \mathrm{~cm}$, thick and sturdy stems, leaves that are thick, dark green and erect, a vigorous root system, 100-130 days growth duration and increased harvest index (Peng et al., 1994). However, these did not yield well because of limited biomass production and poor grain filling (Peng and Khush, 2003).

Increase in temperature, depending upon the current ambient temperature, can reduce crop duration, increase crop respiration rates, alter photosynthate partitioning to economic products, affect the survival and distribution of pest populations thus developing a new equilibrium between crops and pests, hasten nutrient mineralization in soils, decrease fertilizer use efficiencies and increase evapotranspiration. The stages of growth at which weather extremes occur is important in determining yield losses. For example, a temperature increase for a short period around pollen formation, dispersal and germination can lead to partial/complete sterility in crops (Horie, 1993).

Depending upon the current temperatures and thresholds, increased temperature can sometimes result in yield increase. Easterling et al. (2007) have shown that an increase in temperature of up to $3{ }^{\circ} \mathrm{C}$ could result in increased yields of cereals in temperate environ- 
ments, whereas in tropical countries yields could start decreasing with a small increase in temperature. This has implications on global food trade. It is expected that due to rising food demands and decreased production associated with global warming in tropical countries, trade flows of food would increase from temperate countries to tropics. Fischer et al. (2002b) estimate that by 2080 cereal imports by developing countries would rise by $10-40 \%$.

Rainfall, and hence availability of water, is the major limiting factor in the growth and production of crops worldwide. Plants need adequate moisture, especially during critical stages of germination and fruit development. Irrigation systems have been developed around the world by many countries to ensure crop water supply. However, despite this, large areas still remain rainfed. In climate change scenarios, globally precipitation is likely to increase, with large spatial and temporal variation. These changes in precipitation, especially increased frequency of heavy rainfall events, would lead to increased probability of droughts and floods, in turn, affecting food production stability.

Frost causes significant damage to crops, especially to cruciferous and solanaceous crops such as mustard and potato in higher latitudes. Increasing trends in minimum temperatures in future can alleviate this stress in several regions and thus increase yields.

Changes in productivity due to climatic change can also result in geographical shifts of agriculture. This could be accelerated by shifts in the virulence of pathogens and insects. Newman (1980) showed that a $1^{\circ} \mathrm{C}$ increase in mean annual temperature could shift the US corn (maize) belt by approximately $100 \mathrm{~km}$. Carter and Saarikko (1996) showed a similar poleward shift in Finnish cereal cultivation by $100-150 \mathrm{~km}$ for each $1{ }^{\circ} \mathrm{C}$ increase in mean annual temperature. Aggarwal et al. (1995) also showed that wheat cultivation in India is likely to shift northwards with climate change.

Several adaptation strategies can alter crop-climate interactions and thus reduce the adverse impacts on agriculture. Farmers and societies have been increasing their adaptive capacities to changing environments, depending on technological and financial capabilities. For example, establishment of buffer food stocks and agricultural insurance schemes, and development of irrigation infrastructure have been strengthened earlier by many countries to increase their adaptive capacity to climatic extremes such as droughts and floods. Many countries have the historical experience of dealing with climatic variability; climate change may, however, increase its dimensions to outside the range of previous experiences. Potential adaptation strategies for agriculture to mitigate climate change have been suggested which could be implemented by the farmers themselves (Aggarwal et al., 2004; Easterling et al., 2004). These include diversification to more-adapted crops and varieties, changing planting dates, and improving water and fertilizer management. Easterling et al. (2007) showed that the benefits of adaptation vary with crops, regions and temperature changes. In general, such adaptations lead to damage avoidance in grain yields of cereals crops caused by a temperature increase of up to $1.5-3{ }^{\circ} \mathrm{C}$ in tropical regions and $4.5-5{ }^{\circ} \mathrm{C}$ in temperate regions.

\section{Water availability}

One of the significant impacts of global warming is on water resources. This is due to spatially variable changes in precipitation, increased rate of glacier melt and retreat affecting river water flows, greater evaporation due to increase in temperature and higher water demand. These changes are likely to affect all aspects of agricultural water management including irrigation availability, soil moisture, evapotranspiration and run-off.

The balance among precipitation, evaporation, run-off and soil drainage determines soil moisture. Climate variability, interseasonal as well as annual, is known to affect water levels in aquifers. Changes in temperature and precipitation associated with global warming will alter recharge to groundwater aquifers, causing shifts in water table levels (IPCC, 2001). Increase in sea levels may also lead to salinity intrusion in coastal aquifers. In several regions such as South Asia, it is projected that the rainfall intensity may increase. Such changes may result in higher runoff and hence less groundwater recharge.

Arnell (2004) and Nohara et al. (2006) simulated the change in run-off in various parts 
of the world under different scenarios of climate change. Their results showed an increased runoff in high latitudes and the wet tropics, and decreased run-off in mid-latitudes and some parts of the dry tropics. Consequent declines in water availability are therefore projected to affect some of the areas currently suitable for rainfed crops (Easterling et al., 2007).

The increased melting and recession of glaciers associated with global climate change could further change the run-off scenario. The IPCC in its recent report has shown that glaciers all over the world are receding at a rapid rate (IPCC, 2007a). In recent decades, Himalayan glaciers have receded between 2.6 and $28 \mathrm{~m} /$ year (Kulkarni and Bahuguna, 2002). Mass balance studies indicate significant increase in glacial degraded run-off volume in the last decade, from $200 \mathrm{~mm}$ in 1992 to $455 \mathrm{~mm}$ in 1999 (Dobhal et al., 2004).

With $70 \%$ of the global water withdrawals and $90 \%$ of the global water consumption, the irrigation sector is the dominant water use sector at the global scale. According to an FAO (Food and Agriculture Organization of the United Nations) projection of agriculture in developing countries (Bruinsma, 2003), the developing countries would like to expand their irrigated area by $20 \%$ by 2030 . Most of this expansion will occur in already water-stressed areas, such as South Asia and North Africa. Such an analysis does not consider increased irrigation requirements due to global-warmingassociated increase in evaporative demand. Doll (2002) projected significant change in the net irrigation requirements for the global scale due to climatic changes. Depending on emissions scenario and climate model, global net irrigation requirements were found to increase by $1-3 \%$ until 2025 and by $2-7 \%$ until 2075. Fischer et al. (2006) computed increases in global net irrigation requirements of $20 \%$ by 2080, with large spatial variations. Predicted increased variability of precipitation, which includes longer drought periods, would also lead to an increase in irrigation requirements, even if the total precipitation during the growing season remained the same (Eheart and Tornil, 1999).

The above results show that irrigation requirement may increase in future. In contrast, we can expect in future a scenario of reduced water supply for agriculture due to the effects of global climatic changes on the hydrological cycle, increasing competition from industry/urban areas, and currently declining trends of groundwater tables. Production of an increased quantity of food with decreasing availability of quality irrigation water would, therefore, be a big challenge for the agricultural community.

\section{Soil suitability}

Changes in precipitation patterns and amount, and temperature can influence soil water content, run-off and erosion, workability, temperature, salinization, biodiversity, and organic carbon and nitrogen content (Van Ittersum et al., 2003; Nearing et al., 2004). Changes in soil water induced by global climate change may affect all soil processes and ultimately crop growth. Increase in temperature would also lead to increased evapotranspiration, which may result in lowering of the groundwater table at some places. Increased temperature coupled with reduced rainfall enhances upward water movement, leading to accumulation of salts in upper soil layers. Similarly, rise in sea level associated with increased temperature may lead to saltwater ingression in the coastal lands, making them unsuitable for conventional agriculture.

The contribution of agriculture globally to greenhouse gas emissions is $13.5 \%$ (IPCC, 2007b), although there are large regional variations. Mitigating emission of greenhouse gases is today a global priority. Even though the contribution of agriculture is small, there are options available that can assist in reducing greenhouse gas emissions. Improved water and fertilizer management in rice fields, use of nitrification inhibitors such as neem-coated urea and efficient use of energy are some examples. Increasing the area under biofuels and agroforestry could also mitigate greenhouse gas emissions. However, this may have trade-offs with the goal of increasing food production.

Rapidly increasing demand for biofuels in North America and Europe is making fundamental changes to agricultural markets and is likely to keep the prices of agricultural commodities high over the next decade, according to a recent report by the Organization for Economic Cooperation and Development (OECD) and the 
FAO (OECD-FAO, 2007). The study indicates that in the next 10 years (2009 onwards), substantial amounts of maize in the USA, wheat and rapeseed in the EU and sugar in Brazil will be used for ethanol and biodiesel production. It also indicates that high demand for biofuel feedstocks, such as cereals, sugar, oilseeds and vegetable oils, is likely to contribute to a $20-50 \%$ rise in international commodity prices over the next 10 years, in comparison with the 1997-2007 average. At the same time, the surging use of maize and other cereals for biofuel production decreases their availability for food, industry and poultry. There is considerable interest in growing more biofuels even in developing countries that are generally short of food.

Recent researches have shown that surface seeding or zero tillage establishment of upland crops after rice gives similar yields to those planted under normal conventional tillage over a diverse set of soil conditions. This reduces the cost of production, allows earlier planting and thus higher yields, results in less weed growth, reduces the use of natural resources such as fuel and steel for tractor parts, and shows improvements in efficiency of water and fertilizers (RWC-CIMMYT, 2003). In addition, such resource-conserving technologies restrict release of soil carbon, thus mitigating increase of $\mathrm{CO}_{2}$ in the atmosphere. It is estimated that zero tillage saves at least $30 \mathrm{l}$ of diesel as compared with conventional tillage. This leads to $80 \mathrm{~kg} / \mathrm{ha} /$ year reduction in $\mathrm{CO}_{2}$ production (Grace et al., 2003). If this saving could be translated even partially to large arable areas, substantial $\mathrm{CO}_{2}$ emissions to the atmosphere could be reduced.

\section{Crop-pest interactions}

It is estimated that insect pests, pathogens and weeds result in almost $30 \%$ loss in crop production at present. Avoidance of such loss constitutes one of the main sources of sustainability in crop production. Change in climate may bring about changes in population dynamics, growth and distribution of insects and pests. Besides having a significant direct influence on the pest population build-up, the weather also affects the pest population indirectly through its effects on other factors like food availability, shelter and natural enemies (Chakraborty and
Datta, 2003; Cocu et al., 2005; Salinari et al., 2006).

Aphid is a major pest of wheat and its occurrence is highly influenced by weather conditions. Cloudy weather with high relative humidity favours the occurrence of aphids in the field. Under most favourable conditions, a population density of 1000 million/ha in a wheat field has been reported. Weather changes may lead to aphid occurrence at the very juvenile and more susceptible stage of the crop, leading to tremendous loss. In nature, aphids are checked by Coccinella septumpunctata, and in the case where the weather limits Coccinella's growth, the production losses could be further magnified. With small changes, the virulence of different pests changes. For example, at $16{ }^{\circ} \mathrm{C}$, the length of latent period is small for yellow rust. Once the temperature goes beyond $18{ }^{\circ} \mathrm{C}$, this latent period increases but that of yellow and stem rusts decreases. Appearance of black rust in north India in the 1960s and 1970s was related to the temperature-dependent movement of spores from south to north India. Thus, any small change in temperature can result in changed virulence as well as appearance of new pests in a region.

Several pathogens such as Phytophtora and Puccinia group produce abundant propagules from the infected lesion or spot. Invariably they also possess a very short incubation cycle or life cycle period. Such pathogens and pests are highly sensitive to even minor changes in temperature, humidity and sunlight. Any change in the weather conditions that further reduce the incubation period will result in the completion of more cycles, greater terminal severity and much more severe yield losses. Changes in maximum or minimum temperature, even to the extent of $1^{\circ} \mathrm{C}$, will make all the difference between moderate and severe terminal disease development. Swarms of locusts produced in the Middle East usually fly eastward into Pakistan and India during the summer season and they lay eggs during the monsoon period. Changes in rainfall, temperature and wind speed pattern may influence the migratory behaviour of locusts.

Most crops have $\mathrm{C}_{3}$ photosynthesis (responsive to $\mathrm{CO}_{2}$ ) and many weeds are $\mathrm{C}_{4}$ plants (non-responsive to $\mathrm{CO}_{2}$ ). Climate change characterized by higher $\mathrm{CO}_{2}$ concentration will 
favour crop growth over weeds, although temperature increase may further accelerate crop-weed competition, depending upon the threshold temperatures in different locations.

\section{Socio-economic constraints}

In addition to the biophysical determinants discussed above, the socio-economic environment, including government policies, capital availability, prices and returns, infrastructure, land reforms and inter- and intranational trade, is also an equally important determinant of crop production and hence food supply. Global environmental changes may alter the interactions between biophysical and socioeconomic factors and the ways in which these are mediated by the institutions. Some recent studies have linked the biophysical response of crops, costs-benefits and the expected response of farmers to understand the socio-economic impact of global change. In the USA, maize production losses due to extremes of climate may double during the next 30 years, causing estimated additional damages of US $\$ 3$ billion per year (Rosenzweig et al., 2002). Developing countries are thought to be more vulnerable to extremes of climatic variability owing to their limited institutional and adaptation capacity.

Simulation studies involving biophysical and socio-economic modelling indicate that climate change is likely to increase the number of people at risk of hunger, depending on projected socioeconomic developments. Fischer et al. (2002a) estimate that climate change will increase the number of undernourished people in 2080 by 5-26\%. Parry et al. (2004, 2005), however, project small reductions by 2080, depending upon the climate change scenario. These studies also indicate that in future sub-Saharan Africa is likely to become the most food-insecure region of the world, and by 2080 may account for $40-50 \%$ of all undernourished people (Fischer et al., 2002a; Parry et al., 2004).

\section{Conclusions}

Changes in food demands, markets and agricultural technologies have led to major changes in the structure and function of agricultural ecosystems around the world. The pace of these changes is expected to increase rapidly in the coming years, and the whole agricultural scenario may become quite different in the next 10 to 20 years. Global climatic changes and increasing climatic variability are likely to further exert pressure on agricultural systems and change the balance among the key determinants of crop growth and yield. Efforts to assess the impacts, adaptation measures and vulnerability to climate change in this changing world scenario need to be strengthened.

\section{References}

Aggarwal, P.K. (2003) Impact of climate change on Indian agriculture. Journal of Plant Biology 30, 189-198. Aggarwal, P.K., Kalra, N., Bandyopadhyay, S.K. and Selvarajan, S. (1995) A systems approach to analyse production options for wheat in India. In: Bouma, J., Kuynehoven, A., Bouman, B.A.M., Lutyen, J.C. and Zandstra, H.G. (eds) Eco-regional Approaches for Sustainable Land Use and Food Production. Kluwer, the Netherlands, pp. 167-186.

Aggarwal, P.K., Talukdar, K.K. and Mall, R.K. (2000) Potential yields of rice-wheat system in the Indo-Gangetic plains of India. Rice-Wheat Consortium Paper Series 10. RWCIGP, CIMMYT, New Delhi, India.

Aggarwal, P.K., Joshi, P.K., Ingram, J.S. and Gupta, R.K. (2004) Adapting food systems of the Indo-Gangetic plains to global environmental change: key information needs to improve policy formulation. Environmental Science \& Policy 7, 487-498.

Arnell, N.W. (2004) Climate change and global water resources. SRES emissions and socio-economic scenarios. Global Environmental Change 14, 31-52.

Bhalla, G.S., Hazell, P. and Err, J. (1999) Prospects for India's cereal supply and demand for 2020. Food, Agriculture and the Environment Discussion Paper 29. IFPRI, Washington, USA.

Bruinsma, J. (ed.) (2003) World Agriculture: Towards 2015/2030. An FAO Perspective. Earthscan, UK.

Carter, T.R. and Saarikko, R.A. (1996) Estimating regional crop potential in Finland under a changing climate. Agricultural and Forest Meteorology 79, 301-313. 
Chakraborty, S. and Datta, S. (2003) How will plant pathogens adapt to host plant resistance at elevated $\mathrm{CO}_{2}$ under a changing climate? New Phytologist 159, 733-742.

Cocu, N., Harrington, R., Rounsevell, A., Worner, S.P. and Hulle, M. (2005) Geographical location, climate and land use influences on the phenology and numbers of the aphid, Myzus persicae, in Europe. Journal of Biogeography 32, 615-632.

Dobhal, D.P., Gergan, J.T. and Thayyen, R.J. (2004) Recession and morphogeometrical changes of Dokriani glacier (1962-1995), Garhwal Himalaya, India. Current Science 86, 692-696.

Doll, P. (2002) Impact of climatic change and variability on irrigation water requirements: a global perspective. Climatic Change 54, 269-293.

Easterling, W.E., Hurd, B. and Smith, J. (2004) Coping with Global Climate Change. The Role of Adaptation in the USA. Pew Center on Global Climate Change, USA.

Easterling, W.E., Aggarwal, P.K., Batima, P., Brander, K.M., Erda, L., Howden, S.M., Kirilenko, A., Morton, J., Soussana, J.-F., Schmidhuber, J. and Tubiello, F.N. (2007) Food, fibre and forest products. In: Parry, M.L., Canziani, O.F., Palutikof, J.P., van der Linden, P.J. and Hanson, C.E. (eds) Climate Change 2007: Impacts, Adaptation and Vulnerability. Contribution of Working Group II to the Fourth Assessment Report of the Intergovernmental Panel on Climate Change, Cambridge University Press, Cambridge, UK, pp. 273-313.

Eheart, J.W. and Tornil, D.W. (1999) Low-flow frequency exacerbation by irrigation withdrawals in the agricultural Midwest under various climate change scenarios. Water Resources Research 35, 2237-2246.

FAO (2006) The State of Food Insecurity in the World. FAO, Rome.

Fischer, G., Shah, M. and van Velthuizen, H. (2002a) Climate Change and Agricultural Vulnerability. IIASA Special Report commissioned by the UN for the World Summit on Sustainable Development, Johannesburg 2002. International Institute for Applied Systems Analysis, Laxenburg, Austria.

Fischer, G., van Velthuizen, H., Shah, M. and Nachtergaele, F.O. (2002b) Global Agro-ecological Assessment for Agriculture in the 21st Century: Methodology and Results. Research Report RR-02-02. International Institute for Applied Systems Analysis, Laxenburg, Austria, and CD-Rom.

Fischer, G., Tubiello, F.N., van Velthuizen, H. and Wiberg, D. (2006) Climate change impacts on irrigation water requirements: effects of mitigation, 1990-2080. Technological Forecasting and Social Change 74, 1083-1107.

Grace, P.R., Jain, M.C., Harrington, L. and Philip Robertson, G. (2003) The long-term sustainability of tropical and subtropical rice and wheat systems: an environmental perspective. In: Improving the Productivity and Sustainability of Rice-Wheat Systems: Issues and Impacts. ASA Special Publication 65. American Society of Agronomy, Madison, USA, pp. 27-43.

Horie, T. (1993) Predicting the effects of climatic variation and effect of $\mathrm{CO}_{2}$ on rice yield in Japan. Journal of Agricultural Meteorology (Tokyo) 48, 567-574.

Hossain, M. (1995) Sustaining food security for fragile environments in Asia: achievements, challenges and indications for rice research. In: Fragile Lives in Fragile Ecosystems. International Rice Research Institute, Los Baños, The Philippines, pp. 3-25.

IPCC (2001) Climate Change 2001: Impacts, Adaptation and Vulnerability. Intergovernmental Panel on Climate Change, Report of the Working Group II. Cambridge University Press, Cambridge, UK.

IPCC (2007a) Climate Change 2007. The Physical Science Basis. Contribution of Working Group I to the Fourth Assessment Report of the Intergovernmental Panel on Climate Change. Solomon, S., Qin, D., Manning, M., Chen, Z., Marquis, M., Averyt, K.B., Tignor, M. and Miller, H.L. (eds), Cambridge University Press, Cambridge, UK.

IPCC (2007b) Climate Change 2007: Mitigation. Contribution of Working Group III to the Fourth Assessment Report of the Intergovernmental Panel on Climate Change. Metz, B., Davidson, O.R., Bosch, P.R., Dave, R. and Meyer, L.A. (eds), Cambridge University Press, Cambridge, UK.

Khush, G.S. (1995) Breaking the yield frontier of rice. Geo Journal 35, 329-332.

Kimball, B.A., Kobayashi, K. and Bindi, M. (2002) Responses of agricultural crops to free-air $\mathrm{CO}_{2}$ enrichment. Advances in Agronomy 77, 293-368.

Kulkarni, A.V. and Bahuguna, I.M. (2002) Glacial retreat in the Baspa basin, Himalaya, monitored with 17 satellite stereo data (Correspondence). Journal of Glaciology 48 (160), 171-172.

Kumar, P. (1998) Food demand and supply projection for India. Agricultural Economics Policy Paper 98-01, Indian Agricultural Research Institute, New Delhi, India.

Long, S.P., Ainsworth, E.A., Leakey, A.D.B., Nosberger, J. and Ort, D.R. (2006) Food for thought: lower expected crop yield stimulation with rising $\mathrm{CO}_{2}$ concentrations. Science 312, 1918-1921.

Nearing, M.A., Pruski, F.F. and O' Neal, M.R. (2004) Expected climate change impacts on soil erosion rates: a review. Journal of Soil Water Conservation 59, 43-50. 
Newman, J.E. (1980) Climate change impacts on the growing season of the North American corn belt. Biometeorology 7(2), 128-142 (Supplement to International Journal of Biometeorology 24 (December 1980)).

Nohara, D., Kitoh, A., Hosaka, M. and Oki, T. (2006) Impact of climate change on river discharge projected by multimodel ensemble. Journal of Hydrometeorology 7, 1076-1089.

OECD-FAO (2007) OECD-FAO Agricultural Outlook 2007-2016. OECD/FAO, Rome, Italy.

Parry, M.L., Rosenzweig, C., Iglesias, A., Livermore, M. and Fischer, G. (2004) Effects of climate change on global food production under SRES emissions and socio-economic scenarios. Global Environmental Change 14, 53-67.

Parry, M.L., Rosenzweig, C. and Livermore, M. (2005) Climate change, global food supply and risk of hunger. Philosophical Transactions of Royal Society B 360, 2125-2138.

Peng, S. and Khush, G.S. (2003) Four decades of breeding for varietal improvement of irrigated lowland rice in the International Rice Research Institute. Plant Production Science 6, 157-164.

Peng, S., Khush, G.S. and Cassman, K.G. (1994) Evaluation of a new plant ideotype for increased yield potential. In: Cassman, K.G. (ed.) Breaking the Yield Barrier. Proceedings of a Workshop on Rice Yield Potential in Favorable Environments. International Rice Research Institute, Los Baños, The Philippines, pp. 5-20.

Rosegrant, M.W., Sombilla, M. and Perez, N.D. (1995) Global food projections to 2020: implications for investment, food, agriculture and the environment. Discussion Paper No. 5. IFPRI, Washington, DC, USA.

Rosenzweig, C. and Parry, M.L. (1994) Potential impact of climate change on world food supply. Nature 367, 133-138.

Rosenzweig, C., Tubiello, F.N., Goldberg, R., Mills, E. and Bloomfield, J. (2002) Increased crop damage in the US from excess precipitation under climate change. Global Environmental Change 12, 197-202.

RWC-CIMMYT (2003) Addressing Resource Conservation Issues in Rice-Wheat Systems of South Asia: a Resource Book. Rice-Wheat Consortium for the Indo-Gangetic Plains - International Maize and Wheat Improvement Center, New Delhi, India.

Salinari, F., Giosue, S., Tubiello, F.N., Rettori, A., Rossi, V., Spanna, F., Rosenzweig, C. and Gullino, M.L. (2006) Downy mildew epidemics on grapevine under climate change. Global Change Biology 12, 1-9.

Van Ittersum, M.K. and Rabbinge, R. (1997) Concepts in production ecology for analysis and quantification of agricultural input-output combinations. Field Crops Research 52, 197-208.

Van Ittersum, M.K., Howden, S.M. and Asseng, S. (2003) Sensitivity of productivity and deep drainage of wheat cropping systems in a Mediterranean environment to changes in $\mathrm{CO}_{2}$, temperature and precipitation. Agriculture Ecosystems and Environment 97, 255-273. 